\title{
Meet The Occupational Health Nurse
}

\author{
Y. Campbell, R.G.N., R.M., O.H.N. \\ Occupational Health Nurse In the Field
}

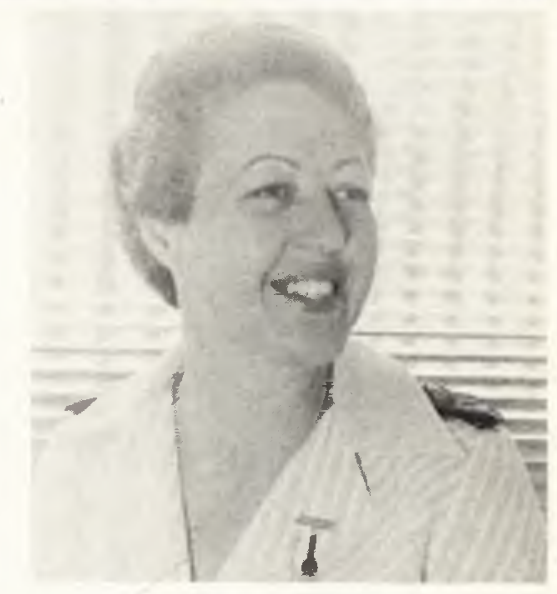

\section{OPSOMMING}

Dat beroepsgesondheidsdienste groter produktiwiteit beteken, is tydens albei wêreldoorloë bewys, sodat die beroepsgesondheidsverpleegster onbeperkte geleenthede het.

Aangesien belangstelling in the gesondheid van die werker diepe betrokkenheid in sy werk verg is dit die algemene doelstelling van ' $n$ beroepsgesondheidsdiens om die gesondheid van die werker te bevorder - die aanpassing van die werk by die mens en die mens by die werk.

Hierdie gebied handel nie net oor beroepsrisiko's- en siektes nie, maar sluit alle faktore in wat betrekking het op werktoestande wat siekte of afwyking van gesondheid veroorsaak of daartoe bydrae.

T HE great upsurge of knowledge and progress in occupational health medicine which occurred during both world wars was proof that good occupational health services mean greater productivity, with the result that today the scope of the occupational health nurse is unlimited.

Who is the occupational health nurse and what is required of her in this field of nursing? What exactly is the scope of such a service?

In the past she was referred to as an industrial nurse, as the majority were employed by industries. The title has since been changed to occupational health nurse because it is not only the industrial field which is concerned with the health of employees, but also commerce, shipping. railways, mines, forestry, agriculture and others. Since interest in the health of the worker calls for close involvement with his occupation. the title occupational health nurse is more appropriate.

Besides having the basic qualifications (general nursing and midwifery), the occupational health nurse should also have had some training or experience in psychology, medical ethics, environmental hygiene, legislation, pollution, industrial diseases and industrial safety. She requires proficiency in handling medical and surgical emergencies, chronic diseases, rehabilitation - medical, surgical and mental - and should have a sound working knowledge of epidemiology.
The overall objective of her service is to promote the general health of the worker - the adjustment of work to man, and man to work.

This is a field of nursing which is advancing rapidly all over the world. Its scope, formerly limited mainly to occupational hazards causing accidents and occupational disease, now embraces all factors related to working conditions which may cause or contribute to disease, or deviation from health.

The occupational health nurse and the medical staff are essentially part of the working complex as a whole - not an isolated group of people working in a medical centre. They are part of a team and must always work as a team with members of other departments. Ideally, the management, the company medical officer, the occupational health nurse, the medical assistants, the safety officer, and the workers themselves should form a team which is geared to protect the health of the worker and to prevent occupational diseases and accidents. More specifically, in the sphere of company administration there should be good communication between management, worker and the occupational health nurse, so that problems can be discussed sensibly and without any fear of prejudice. People need to get to know one another in order to understand one another's viewpoints. Without this total co-operation and teamwork a health programme will fail. 
It should also be remembered that companies and organisations are concerned with a high standard of productivity. They are in business to make a profit, and the better the production, the bigger the profit. An important aspect of occupational health nursing is to keep the healthy man healthy - in other words, our field of nursing is as much preventive as curative in nature. Health promotion applies to all nursing services, but is particularly pertinent to our field.

Occupational health nurses work in medical centres which vary in size. While some have just one room in which to work, others have a complete hospital complex with X-ray units, sterilizing rooms with autoclaves, etc. Many organisations have either a full-time or part-time medical officer, but in some instances the occupational health nurse works entirely on her own. Many black nurses are employed in the service - both male and female - including registered and enrolled nurses or enrolled assistant nurses. Their help regarding tribal customs and communication among their own people is invaluable.

The occupational health nurse may be responsible for appointing medical centre staff. Careful selection of personnel is necessary as the medical team must be responsive to other people. It is to them that the unhappy or the sick worker comes, and because he is sick or unhappy, he is unsure of himself. He is afraid, and needs understanding and sympathy. The occupational health team must be people of understanding.

Training of the staff is very important. Every procedure must be clearly explained to them. They must know to whom they are responsible, what specific tasks are required of them and this "job description" should be reviewed from time to time. Lines of communication, medical ethics and protocol should be clearly explained by the occupational health nurse to her staff, as people are very sensitive to their responsibilities and, if bypassed, may become resentful. This could cause a major upset in the teamwork of the medical centre.

With regard to her own position in the organisation, the ideal situation is for the occupational health nurse to be responsible to the company medical officer for the nursing aspects of her role, and to the personnel manager for the administrative side of the medical service. She should have ready access to all top senior managers as a situation may arise which necessitates discussion with a person in authority, and be recognised by all employees, and by the employer, as a mature, responsible person to make decisions which could affect the welfare of employees.

A good relationship between the occupational health nurse and the workers is essential. The worker must get to know her, not only in the medical centre, but also as a visitor on the job. The worker should feel that she is interested not only in his health, but also in him as a person. She should get to know his family, social background, outside stresses, his ambi tions, hopes, frustrations and failures. Confidential personal information entrusted to the occupational health nurse must be respected as such.

The occupational health nurse must be aware that no programme should ever be static. It should change in accordance with the changing needs of the organisation.

In each sphere of occupational health nursing there are routine and specific nursing programmes.

Under the heading of routine work one could begin with the preplacement medical examination - one of the preventive aspects of occupational health nursing — for at this stage a man's health can be ascertained before ever he commences work.

The examination would cover areas such as height and weight, bloodpressure, urine analysis, eye-testing and a physical examination for any deformities.

After the examination the medical officer and the occupational health nurse will be able to assess the man's suitability for a specific position and here the occupational health nurse plays an important part.

She must know exactly what type of work is involved in the position offered.

To this end it is her responsibility, on taking up her post, to visit every department of the factory, to get to know it and its working procedures, so that when a person comes for a pre-employment medical examination she knows exactly what type of work is involved in the position offered.

The physical examination should be repeated at regular intervals, i.e. the periodic examination, when also it will be ascertained whether certain substances used in the factory (lead or asbestos among others) are affecting the worker's health.

Furthermore, the employee should be physically checked on termination of service for an occupational disease or injury for which claims may be made at a later date.

After a long illness the worker should be re-examined to decide whether he is really fit to return to his job.

The medical centre should always be research-oriented. Note should be taken of new processes in the factory and if there is a high sickness record pertaining to any particular area, investigation should be made to ascertain whether new processes are being used and with what detrimental effects.

\section{Record-keeping is another routine task.}

An individual card records all information such as dates and times of visits to the medical centre, complaints, diagnoses and treatment. This should be done meticulously as the occupational health nurse may have to refer to these records should she be required to give evidence in court. Some records are legally essential and she must be aware of changes in company policies, building alterations and activities in the factory in order to be able to comply with the legal requirements.

Documentation covering workmen's compensation is controlled by the occupational health nurse and here she can 
play an important part in seeing that the injured worker receives any compensation due to him. Rehabilitation of the worker who has suffered a severe injury or illness is yet another area where the occupational health nurse is involved and can only be successfully achieved if there is a good working liaison with the departmental managers, and outside authorities including physiotherapists and private medical practitioners.

The treatment of injuries and illnesses at work - the curative aspect of occupational health nursing, is an important section. Employees who have sustained injuries at home are likewise encouraged to report for early treatment at the medical centre. In this way injury is assessed, the necessary treatment carried out at work (if possible), so saving precious man-hours, and a close watch can be kept on the progress of the injured man. Suitable light work can be arranged if necessary, and this will help in control of sick leave absence. In the same way. employees suffering from injuries on duty are rehabilitated as soon as possible. Here, a good working relationship with outside private medical practitioners is important.

This aspect of occupational health nursing is important to companies and organisations, as by keeping men on the job, or rehabilitating them as soon as possible, the medical centre is helping to maintain the maximum production possible, while at the same time assisting the workers themselves.

As the medical centre works on an annual budget a strict control of the use of medications and dressings is an administrative aspect of the job.

The occupational health nurse should be a member of the safety committee to which she can make a valuable contribution by helping to reduce accidents.

Where she notices an increase of minor injuries in one particular department early investigation as to the cause could prevent the occurrence of a major injury.

She could be involved in organising first aid training of employees, and the more workers thus trained the lower is likely to be the accident rate.

On her visits to the factory floor she should keep an alert eye on the safety aspect of the factory housekeeping, as for instance checking aisles and stacking in the warehouse. Are the machine guards and lockout systems effective enough in the production area? Are the stairs safe? Is the respiratory and personnel-protective equipment adequate?

By furthering safety education the occupational health nurse becomes the co-ordinator in the safety programme. She is a teacher - teaching safety.

Industrial and environmental hygiene is another aspect of her work.

She will carry out special tests and examinations on employees working in particular areas or doing a particular type of work. Dusty and noisy areas come into these categories as do those where there is danger of lead absorption. Among the workers tested are food handlers, heavy duty and fork-lift drivers and handlers of dangerous chemicals. She will be watching out for signs that may indicate a breakdown in the health of these workers who must be made aware of the hazards with which they may be confronted in order to enable them to take precautions - and - she must be in a position to advise them when problems arise.

It is essential, therefore, that she receives adequate training in these areas and that she fully understands the types of machines used, the hazardous substances to which workers will be exposed and, of course, the working conditions. Only with this knowledge will she be aware of the danger areas and of the precautions to be taken. This training should be ongoing, especially when new machines are instalied or new procedures introduced.

Both the doctor and the occupational health nurse should be fully conversant with the types of jobs and the requirements for everyone in the factory so that they can give full protection to the worker and the employer, providing a treatment service while primarily a preventive service.

Let us look at the chronic disease clinics which can be controlled by the occupational health nurse.

Many are involved in the programme in the fight against tuberculosis. Annual mass miniature chest $\mathrm{X}$-rays can be arranged through the local public health department and supervised treatment of positive cases can be carried out at the place of employment, thus again saving time lost and reducing the numbers attending a local public health clinic. Weight control checks are maintained and a suitable high protein diet is advised.

The importance of regular medication cannot be sufficiently stressed, and the occupational health nurse plays a vital role not only in administering the treatment, but in counselling the workers. Ignorance could lead to a lapse whilst taking treatment.

Another important point to remember is the need for continued reassurance of financial support and employment, should these patients of necessity be admitted to a tuberculosis hospital. In many cases the worker is the breadwinner, and unless he receives genuine reassurance, he will abscond from the treatment centre in a desperate bid to find a means of supporting his family. The continued reassurance of employment must hasten his recovery. If a worker on treatment requests leave, the occupational health nurse should issue sufficient medications plus a covering letter clearly indicating his treatment so that should a breakdown in health occur during this period, suitable assistance could be given. Many black workers proceed to the homelands for their annual vacation, and, armed with such a letter for the local authorities, much misunderstanding can be avoided.

The same type of procedure applies to the control of venereal disease. Blood specimens can be taken at the medical centre and treatment given - again working through the local health authorities - but keeping the workers at work.

If they so desire, employees suffering from illness such as hypertension, diabetes, epilepsy, asthma, etc. may receive treatment through the medical centre, which will help relieve 
pressure at the out-patient departments of our local hospitals and clinics. Health education talks can be given, as and when the occasion arises, on diets and the importance of taking the medications. If facilities are not available at the place of work there are sources of referral which should be fully utilised.

In the same way, various screening programmes can be organised for the investigation of typhoid, syphilis and bilharzia, and immunisation programmes conducted in the event of outbreaks of influenza, smallpox, polio, tetanus, etc. Here again, let me stress that the occupational health nurse is a member of a team which should co-operate with all other teams interested in the welfare of the employee.

Many occupational health nurses work in companies where females are employed. With the cognizance of the local public health department, cervical screening can be done at the medical centre, and positive results referred to the employee's private medical practitioner for further treatment. A family planning service is also rendered, available both to men and women.

The alcoholic and the drug addict, too, need the occupational health nurse's help and here she can co-operate with referral centres and the social worker in rehabilitation of these employees.

The occupational health nurse should take particular interest in vulnerable groups - women, the aged, the disabled, the young inexperienced employee and those recovering from illness or accidents. Counselling plays a big part in the health programme. Many people come to work with problems and many have problems at work. They need to be able to speak to someone about them. By listening intelligently the occupational health nurse can often detect the area in which the employee is unhappy in the work situation and can then take steps to help put it right. Many of the workers have family problems and while sometimes just lending a listening ear will help, often these people need referral for further assistance. It is essential, therefore, for the nurse to be aware of the appropriate organisations which are available.

Another aspect of the role of the occupational health nurse is sick visiting. In this capacity she assesses the situation, the need for assistance where this arises and reassures the employee that he still has a job.

Finally, as it is essential to keep up with modern trends in the nursing field as a whole, the occupational health nurse should participate in discussion groups, attend seminars and read widely in order to enable her to fulfil her role in the team of which she is a member. . .

It is hoped that some insight has been given into the role of the occupational health nurse, the magnitude of her task, the responsibility she carries and the scope of her field. It is a challenging and rewarding field of nursing — an essential service to the community. 